\title{
PENERAPAN MODEL MAKE A MATCH BERBANTUAN MEDIA PERMAINAN ULAR TANGGA UNTUK MENINGKATKAN HASIL BELAJAR SISWA
}

\author{
Adelina Noorisa ${ }^{1}$, Erik Aditia Ismaya ${ }^{2}$, Mila Roysa ${ }^{3}$ \\ ${ }^{1,2,3}$ Universitas Muria Kudus, Jl. LKr. Utara, Kayuapu Kulon, Gondangmanis, Kec. Bae, Kab. Kudus, Jawa Tengah 59327 \\ jeonjungkook350@gmail.com
}

\begin{abstract}
Abstrak The study aims to improve student learning outcomes in sloving problems with the material by implementing the Make A Match model assisted by snake and ladder media. The subjects of this study were 26 grade IV students with the location of the research carried out in SD 1 Gamong, Kaliwungu District, Kudus Regency. This research lasted for 2 cycles with 2 meatings in each cycle. Data collection techniques are carried out in the form of test and observation sheets. Beston the results of the analysis obtained, it shows that the application of the Make A Match model with the assistance of snake and ladder media on theme 7 especially in social studies content and indonesian can improve student learning outcomes. This research is expected that other researchers can develop learning using the Make A Match model to be more effective by paying more attention to learning syntax and paying attention to the characteristics of the subjects and materials to be used.
\end{abstract}

Keywords: Result, Make A Match

\begin{abstract}
Abstrak
Penelitian ini bertujuan untuk meningkatkan hasil belajar siswa dalam pemecahan masalah terhadap materi dengan melakukan penerapan model Make A Match berbantuan media ular tangga. Subjek penelitian ini adalah siswa kelas IV yang berjumlah 26 orang dengan lokasi penelitian yang dilaksanakan di SD 1 Gamong Kecamatan Kaliwungu Kabupaten Kudus. Penelitian ini berlangsung salama 2 siklus dengan 2 pertemuan di setiap siklusnya. Teknik pengumpulan data yang dilakukan berupa tes dan lembar observasi. Berdasarkan hasil analisis yang diperoleh menunjukkan penerapan model Make A Match dengan berbantuan media ular tangga pada tema 7 Indahnya Keberagaman di Negeriku khususnya pada muatan IPS dan Bahasa Indonesia dapat meningkatkan hasil belajar siswa. Penelitian ini diharapkan agar peneliti lain dapat mengembangkan pembelajaran menggunakan model Make A Match menjadi lebih efektif dengan dapat lebih memperhatikan sintak pembelajaran serta memperhatikan karakteristik mata pelajaran dan materi yang akan digunakan.
\end{abstract}

Kata kunci: Hasil Belajar, Make A Match

\section{PENDAHULUAN}

Belajar dan hasil belajar adalah komponen yang wajib dibutuhkan pada sebuah pendidikan, pendidikan merupakan suatu hal yang penting bagi setiap kehidupan di masyarakat, masyarakat menjadikan suatu pendidikan sebagai hal yang harus wajib untuk diselenggarakan dalam sebuah negara. Kurikulum adalah salah satu komponen utama dalam aktivitas pendidikan, dalam Undangundang Nomor 20 Tahun 2003 tentang Sistem Pendidikan Nasional Pasal 1 butir 19, dijelaskan bahwa kurikulum adalah seperangkat rencana dan pengaturan mengenai tujuan, isi, dan bahan pelajaran serta cara yang digunakan sebagai pedoman penyelenggaraan sebuah kegiatan pada saat proses pembelajaran untuk mencapai tujuan pendidikan tertentu. Kurikulum 2013 adalah salah satu cara pemerintah dalam meningkatkan dan mengembangkan kualitas pendidikan di Indonesia pada pembelajaran di sekolah. Kurikulum 2013 merupakan suatu perangkat yang melibatkan beberapa mata pelajaran yag disusun dalam tematik untuk memberikan pengalaman yang bermakna terhadap para siswa, selain menerapkan pembelajaran secara tematik untuk siswa di kurikulum 2013 ini siswa 
harus dituntut untuk lebih aktif atau pembelajaran harus lebih berpusat kepada siswa dimana bukan guru lagi yang aktif dalam pembelajarannya tetapi siswa juga harus lebih aktif dalam pembelajarannya. Bukan hanya aktif dalam proses pembelajaran siswa juga dituntut untuk mampu mengikuti pembelajaran dengan menggunakan pendekatan saintifik (mengamati, menanya, mengumpulkan informasi, mencoba, dan mengkomunikasikan).

Kenyataan bahwa proses pembelajaran yang ideal dan diharapkan pada kurikulum 2013 ini masih belum terlaksana dengan baik sekarang ini. Hal ini sesuai dengan hasil observasi yang sudah di lakukan pada tanggal 7 Oktober 2019 di SD 1 Gamong Kaliwungu Kudus pada kelas IV, penyebab yang membuat rendahnya hasil belajar siswa dikelas IV khususnya pada mapel IPS dan Bahasa Indonesia ini dikarenakan pemahaman materi siswa yang masih rendah, hal ini dikarenakan adanya banyak siswa yang masih merasa kurang percaya diri ketika ingin bertanya kepada guru tentang materi yang mereka belum pahami sehingga dapat menghambat pemahaman materi yang sudah mereka pelajari, ini mengakibatkan sulitnya penangkapan pemahaman sebuah materi yang kemudian akan berdampak pada hasil belajar siswa.

Wawancara yang telah dilakukan dengan guru kels IV SD 1 Gamong Kudus menunjukkan bahwa hasil belajar yang diperoleh siswa kelas IV pada mapel IPS dan Bahas Idonesia masih terbilang sangat rendah. Hasil wawancara menunjukkan bahwa penyebab hasil belajar siswa rendah adalah dalam pembelajarannya guru belum menerapkan model pembelajaran pada saat proses belajar mengajar selama kurikulum 2013 ini diterapkan sehingga siswa dalam pembelajarannya kurang aktif, dan dalam memahami materi yang sudah diajarkan masih kurang dikarenakan rata-rata siswa masih tidak berani dalam bertanya kepada guru terkait materi yang mereka susah dalam memahami

Data yang telah diperoleh adalah hasil nilai kelas IV SD 1 Gamong Kaliwungu Kudus ini menunjukkan bahwa hasil belajar siswa masih kurang atau rendah. Hasil data yang telah didapatkan adalah hasil belajar dalam ulangan mid semester ganjil pada kelas IV SD 1 Gamong Kaliwungu Kudus yang memperoleh nilai hasil belajar dibawah nilai standar sesuai dalam tuntutan ketuntasan KKM yang sudah ditentukan. Batas ketuntasan pada muatan Bahasa Indonesia dan IPS di kelas IV SD 1 Gamong memiliki batas ketuntasan minimalnya yaitu 75, pada mapel IPS dari 26 siswa yang ada di kelas IV terdapat 15 siswa yang masih mendapatkan nilai dibawah KKM pada ulangan mid semester tahun 2019/2020, kemudian untuk mapel Bahasa Indonesia dari 26 siswa yang ada dikelas IV terdapat 17 siswa yang masih mendapatkan nilai rendah dibawah KKM. Data yang sudah diperoleh ini dapat di simpulkan bahwa dalam hal ini tujuan pembelajaran tidak sesuai dengan apa yang diharapkan, ini disebabkan kurangnya partisipasi siswa dalam mengikuti kegiatan pembelajaran, yang mengakibatkan siswa mudah lupa dengan materi apa saja yang telah disampaikan oleh guru.

Dari permasalahan yang sudah didapatkan, dapat dilihat bahwa proses pembelajaran yang sudah dilaksanakan tidak berjalan dengan optimal, oleh karena itu agar pemahaman materi siswa lebih mudah pada saat pembelajaran, dan hasil belajar peserta didik juga dapat meningkat maka diperlukan sebuah tindakan dan perubahan yang harus dilakukan pada saat proses pembelajaran, yaitu dengan 
Penerapan Model Make A Match Berbantuan Media Permainan Ular Tangga Untuk Meningkatkan Hasil Belajar Siswa,

menerapkan sebuah model pembelajaran dan penggunaan media pembelajaran pada saat proses belajar mengajar. Dalam hal ini penerapan model pembelajaran Make A Match yang berbantuan media permainan ular tangga dan kartu cocok untuk membantu siswa dalam pemahaman materi dan meningkatkan keaktifan siswa dalam proses pembelajaran nantinya.

Make A Match dikembangkan pertama kali oleh Lorna Curran dalam Huda (1994:35) yang memiliki tujuan dianta lainnya adalah: 1) pendalaman materi; 2) penggalian materi; 3) edutainment. Kelebihan dari model pembelajaran ini antara lain yaitu: 1) dapat meningkatkan aktivitas siswa; 2) karena ada unsur permainan, metode ini menyenangkan; 3) meningkatkan pemahaman siswa terhadap materi; 4) efektif sebagai sarana melatih keberanian siswa selama tampil dalam presentasi; dan 5) efektif melatih kedisiplinan siswa menghargai waktu untuk belajar. Model pembelajaran ini sayangnya memiliki beberapa kelemahan antara lain yaitu: 1) jika tidak disiapkan dengan baik akan banyak waktu yang terbuang; 2) awal penerapan, akan banyak siswa yang malu untuk berpasangan; 3) jika guru tidak mengarahkan dengan baik, akan banyak siswa yang kurang memperhatikan presentasi siswa di depan; 4) guru harus hati-hati dalam memberikan sanksi kepada siswa yang tidak dapat pasangan karena bisa menjatuhkan kepercayaan diri siswa; 5) menggunakan metode ini terus menurus akan menimbulkan kebosanan.

Model pembelajaran Make A Match ini pelaksanaannya siswa diajak untuk bermain sambil belajar mengenai suatu konsep atau sebuah topik dengan suasana yang sangat menyenangkan sehingga dapat membuat siswa menjadi lebih aktif dalam kegiatan belajar mengajar. Karakteristik yang dimiliki model pembelajaran Make A Match ini memiliki keterkaitan yang erat dengan karakteristik siswa yang gemar dengan bermain oleh karena itu penerapan model ini akan sangat cocok jika dibantu dengan penggunaan media permainan ular tangga yang diharapkan dapat membantu siswa menjadi semangat dalam melaksanakan kegiatan pembelajaran sehingga proses pembelajaran menjadi aktif dan hasil belajar siswa dapat meningkat.

Model pembelajaran Make A Match dengan berbantuan media permainan ular tangga akan diterapkan dalam pembelajaran tema Indahnya Keberagaman di Negeriku khususnya pada muatan IPS dan Bahasa Indonesia yaitu materi keragaman budaya dan mencari pengetahuan baru teks non fiksi. Model pembelajaran ini dipilih sebagai model yang dianggap tepat untuk menjadi solusi dari permasalahan yang telah ditemukan karena selain dapat meningkatkan pemahaman siswa terhadap materi yang ada, model ini juga membuat siswa menjadi aktif dalam pembelajaran sehingga meningkatkan hasil belajar siswa. Pemilihan tindakan ini dilakukan, dalam penelitian ini perlu juga dikemukakan alasan pemilihan tindakan dan dukungan dari hasil penelitian yang relevan. Erwin Lucky Prasetya (2019) dalam penelitian tindakan kelas nya yang berjudul Peningkatan Hasil Belajar Melalui Model Make A Match Kelas V Tema 1 Organ Gerak Hewan dan Manusia di SDN Kasiyan Pati. Hasil penelitian yang diperoleh bahwa dengan menerapkan model pembelajaran Make A Match dapat meningkatkan hasil belajar siswa, hal ini dilihat dari adanya peningkatan hasil belajar siswa khususnya pada muatan IPA dan Bahasa Indonesia, dari siklus I ke siiklus II mengalami peningkatan 
hasil belajar sebesar $68,18 \%$ siswa yang tuntas belajar, menjadi $86,36 \%$ siswa yang tuntas belajar dengan jumlah siswa sebanyak 16 siswa.

\section{METODE}

Penelitian yang digunakan dalam penelitian ini adalah Peneltian Tindakan Kelas (PTK), Arikunto, dkk (2014:58) berpendapat bahwa Penelitian Tindakan Kelas (PTK) adalah penelitian tindakan (action research) yang dilakukan dengan tujuan memperbaiki mutu praktik pembelajaran di kelasnya. Penelitian ini nantinya akan mendiskripsikan kesulitan siswa dalam belaja pada proses pembelajaran di kelas. Subjek pada penelitian adalah seluruh siswa kelas IV SD 1 Gamong yang berjumah 26 siswa yaitu 17 siswa putri dan 9 siswa laki-laki, kemudian objek dalam penelitian ini adalah penerapan model pembelajaran Make A Match berbantuan media permainan ular tangga di tema 7 Indahnya keragaman di Negeriku terhadap hasil belajar siswa pada mapel IPS dan Bahasa Indonesia.

Bentuk penelitian tindakan kelas pada penelitian ini bertindak pada suatu subjek yang akan diteliti dengan mengimplementasikan atau menerapkan model pembelajaran Make A Match dalam muatan IPS dan Bahasa Indonesia terhadap hasil belajar siswa di tema 7 Indahnya Keragaman di Negeriku, karena adanya tindakan yang diberikan. Prosedur yang dilakukan dalam penelitian ini menerapkan metode penelitian tindakan kelas, maka dari itu penelitian ini terdiri dari beberapa tahapan penelitian yang berupa siklus. Apabila sudah dilakukan peenelitian pada siklus pertama dan hasil belajar yang diperoleh masih tidak sesuai dengan yang diharapkan, maka akan dilakukan ke siklus berikutnya. Penelitian ini dilakukan secara dua siklus dan masing-masing siklus terdiri dari beberapa tahapan yaitu, perencanaan, pelaksanaan/tindakan, pengamatan, dan refleksi. Penelitian ini juga menggunakan beberapa teknik pengumpulan data yaitu teknik tes dan teknik non tes (wawancara, observasi, dan dokumentasi).

Analisis data yang digunakan dalam penilitian ini memiliki dua tipe dalam menganalisis yaitu analisis data secara kuantitatif dan analisis data secara kualitatif.

\section{Data Kuantitatif}

Pengelolaan data secara kuantitatif pada penelitian ini digunakan pada saat menganalisis hasil belajar siswa, dengan cara menggunakan teknik analisis secara deskriptif salam menentukan ketuntasan belajar dan perataan kelas (nilai rata-rata kelas dan nilai ketuntasan belajar secara individu).

\section{Penilaian untuk Ketuntasan}

Penelitian ini akan menggunakan tes evaluasi menggunakan 10 butir soal uraian yang terdiri dari 5 soal muatan IPS dan 5 soal muatan Bahasa Indonesia yang diadakan pada akhir siklus I dan siklus II. Adapun cara penentuan nilai secara individu dapat menggunakan rumus sebagai berikut:

$$
\text { Nilai Akhir }=\frac{\text { Skor Perolehan }}{\text { Skor Maksimal }} \times 100
$$

Apabila sudah memperoleh hasil, selanjutnya peneliti akan mengelompokan hasil belajar menjadi dua kategori yaitu tuntas dan tidak tuntas sesuai dengan KKM di SD 1 Gamong yaitu 75 untuk mapel IPS 
dan Bahasa Indonesia, jika siswa mendapatkan nilai lebih dari 75 maka akan dinyatakan tuntas KKM, dan apabila siswa mendapatkan nilai kurang dari 75 maka siswa tersebut dinyatakan tidak tuntas.

\section{Menghitung Rata-Rata (Mean)}

Menghitung rata-rata akan digunakan untuk menjumlahkan nilai hasil belajar siswa yang telah diperoleh oleh siswa, yang kemudian akan dibagi dengan jumlah siswa yang terdapat pada kelas tersebut.

Nilai rata-rata ini dapat dihitung menggunakan rumus sebagai berikut:

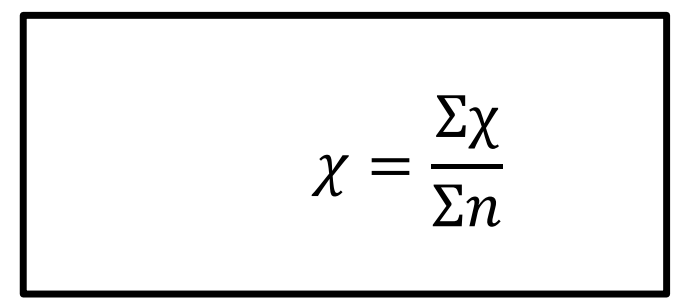

Sumber : (Aqib, 2011: 40)

$$
\begin{aligned}
& \text { Keterangan : } \\
& \chi=\text { nilai rata }- \text { rata } \\
& \Sigma \chi=\text { jumlah semua nilai siswa } \\
& \Sigma n=\text { jumlah siswa }
\end{aligned}
$$

\section{Mengitung Presentase Ketuntasan Belajar secara Klasikal}

Menghitung data ketuntasan belajar secara klasikal dengan rumus sebagai berikut.

$$
\text { Presentase }=\frac{\Sigma \text { siswa yang tuntas belajar }}{\Sigma \text { siswa }} \times 100 \%
$$

Analisis ini dilakukan pada tahapa refleksi, yang kemudian hasil analisis tersebut dijadikan sebagai bahan refleksi dalam memperbaiki rancangan pembelajaran selanjutnya, apabila hasil presentase ketuntasan belajar siswa $<75 \%$ makan ketuntasan belajar klasikal siswa belum bisa tercapai.

Data Kualitatif

Data kualitatif dalam penelitian ini merupakan data yang diperoleh dari hasil observasi yang dilakukan terkait dengan keterampilan guru dalam melakukan pembelajaran yang menerapkan model Make A Match, selain memperoleh data keterampilan dari guru disini peneliti juga akan memperoleh hasil belajar siswa pada aspek keterampilan.

Berikut yang beberapa hal yang diperlukan untuk menganalisis data kualitatif:

\section{Observasi Keterampilan Guru dalam Mengajar}

Penelitian ini menggunakan skala penskoran dan kriteria penilaian yang digunakan untuk lembar observasi keterampilan guru dalam mengajar adalah sebagai berikut: 
Tabel 1.

Pedoman Penskoran Pengelolaan Pembelajaran Guru

\begin{tabular}{|l|c|}
\hline \multicolumn{1}{|c|}{ Kriteria Penilaian } & Skor \\
\hline Pengelolaan pembelajaran guru sangat baik & 4 \\
\hline Pengelolaan pembelajaran guru cukup baik & 3 \\
\hline Pengelolaan pembelajaran guru kurang baik & 2 \\
\hline Pengelolaan pembelajaran guru tidak baik & 1 \\
\hline
\end{tabular}

Sumber: Sugiyono (2010:141)

Setelah dilakukannya rekapitulasi, skor tersebut kemudian dihitung dan di rata-rata dengan menggunakan rumus sebagai berikut:

$$
\text { Presentase }=\frac{\Sigma \text { skor yang diperoleh }}{\Sigma \text { skor maksimal }} \times 100 \%
$$

Hasil yang sudah diperoleh kemudian akan dikonsultasikan dalam kriteria skor pengelolaan pembelajaran oleh peneliti sebagai berikut ini:

\section{Tabel 2.}

Rambu-rambu Analisis Hasil

\begin{tabular}{|l|c|}
\hline \multicolumn{1}{|c|}{ Kriteria } & Nilai \\
\hline Sangat baik & $81-100$ \\
\hline Baik & $62-80$ \\
\hline Cukup & $43-61$ \\
\hline Kurang baik & $25-42$ \\
\hline
\end{tabular}

Sumber (Arifin 2014)

Berdasarkan tabel diatas apabila kriteria yang diperoleh 25-42 maka akan mendapatkan kualifikasi kurang, jika diperoleh kriteria 43-61 makan kualifikasi yang diperoleh cukup, dan kriteria yang diperoleh sebesar 62-80 kualifikasi yang diperoleh akan menjadi baik, yang terakhir apabila mendapatkan kriteria sebesar 81-100 akan mendapatkan kualifikasi sangat baik.

\section{Keterampilan Metakognisi Siswa Ranah Keterampilan}

Hasil belajar siswa yang dinilai tidak hanya dalam aspek pengetahuan tetapi aspek keterampilan pada penelitia ini juga akan dinilai. Adapun cara untuk menghitung perolehan nilai, yaitu sebagai berikut:

$$
\text { Nilai }=\frac{\text { Skor yang diperoleh }}{\text { skor maksimal }} \times 100
$$

Data nilai hasil pengamatan yang sudah diperoleh dengan menggunakan lembar observasi ranah psikomotorik yaitu keterampilan metakognisi siswa, kemudian dapat dianalisis secara kualitatif untuk dapat memperoleh kesimpulan dengan mengategorikan seperti berikut ini: 
Penerapan Model Make A Match Berbantuan Media Permainan Ular Tangga Untuk Meningkatkan Hasil Belajar Siswa, Adelina Noorisa, Erik Aditia Ismaya, Mila Roysa

Tabel 3.

Rentang Predikat Keberhasilan Pembelajaran

\begin{tabular}{|c|c|c|}
\hline No & Nilai & Kriteria \\
\hline 1. & $89<\mathrm{A} \leq 100$ & A (Sangat Baik) \\
\hline 2. & $79<\mathrm{B} \leq 89$ & B (Baik) \\
\hline 3. & $70<\mathrm{C} \leq 79$ & C (Cukup) \\
\hline 4. & $\mathrm{D}<70$ & D (Perlu Bimbingan) \\
\hline
\end{tabular}

Sumber: (Panduan Penilaian Kurikulum 2013)

Berdasarkan tabel diatas, jika skor yang diperoleh kurang dari 70 maka dikualifikasikan perlu bimbingan (D), apabila skor yang diperoleh lebih dari 70-79 maka dikualifikasikan cukup, dan apabila skor yang diperoleh lebih dari 79-89 maka dikualifikasikan baik, jika siswa mendapatkan perolehan skor 89-100 maka dikualifikasikan sangat baik.

\section{HASIL}

Berdasarkan hasil tes evaluasi yang di lakukan pada akhir siklus I dan siklus II, berikut merupakan progres peningkatan hasil tindakan penelitian kelas pada setiap siklus yang sudah dilakukan di kelas IV SD 1 Gamong pada muatan Bahasa Indonesia dan IPS dari mulai prasiklus, siklus I, siklus II setelah dilakukan tindakan. Berikut progres peningkatan hasil belajar pada aspek pengetahuan yang disajikan dalam tabel di bawah ini.

\section{Tabel 4.}

Progres Hasil Belajar Muatan Bahasa Indonesia

\begin{tabular}{lcccccc}
\hline Nama Siswa & KKM & Pra Siklus & $\begin{array}{c}\text { Nilai } \\
\text { Siklus I }\end{array}$ & $\begin{array}{c}\text { Nilai } \\
\text { Siklus II }\end{array}$ & Progres & Keterangan \\
\hline ATR & & & 76 & 77 & Naik-naik & Tuntas \\
AEP & 75 & 63 & 63 & 76 & Naik-naik & Tuntas \\
AM & 75 & 78 & 81 & 85 & Naik-naik & Tuntas \\
AAS & 75 & 45 & 63 & 59 & Naik-turun & Tidak Tuntas \\
AA & 75 & 57 & 76 & 81 & Naik-naik & Tuntas \\
DP & 75 & 45 & 59 & 67 & Naik-naik & Tidak Tuntas \\
EW & 75 & 55 & 55 & 63 & Tetap-naik & Tidak Tuntas \\
FFBG & 75 & 66 & 76 & 76 & Naik-tetap & Tuntas \\
ITM & 75 & 85 & 85 & 90 & Tetap-naik & Tuntas \\
KA & 75 & 63 & 76 & Naik-naik & Tuntas \\
LM & 75 & 55 & 63 & Naik-naik & Tuntas \\
MLH & 75 & 76 & 81 & 85 & Naik-tetap & Tuntas \\
MA & 75 & 77 & 82 & 82 & Turun-naik & Tidak Tuntas \\
MAP & 75 & 59 & 55 & 63 & Naik-turun & Tidak Tuntas \\
MSH & 75 & 48 & 66 & 53 & Naik-naik & Tuntas \\
MCF & 75 & 55 & 63 & 77 & Naik-turun & Tuntas \\
NA & 75 & 75 & 81 & 77 & Naik-tunaik & Tuntas \\
NTR & 75 & 55 & 63 & 76 & Naik-naik & Tuntas \\
NKS & 75 & 63 & 77 & 85 & Naik-naik & Tuntas \\
R & 75 & 59 & 76 & 82 & Naik-naik & Tuntas \\
RZ & 75 & 47 & 57 & 66 & Naik-naik & Tidak Tuntas \\
RMNAF & 75 & 59 & 76 & 81 & Naik-naik & Tuntas \\
SPP & 75 & 78 & 86 & 90 & Naik-naik & Tuntas \\
& 75 & 77 & 75 & 85 & Turun-naik & Tuntas
\end{tabular}




\begin{tabular}{|c|c|c|c|c|c|c|}
\hline SER & 75 & 76 & 82 & 86 & Naik-naik & Tuntas \\
\hline SNA & 75 & 85 & 86 & 95 & Naik-naik & Tuntas \\
\hline SA & 75 & 55 & 63 & 77 & Naik-naik & Tuntas \\
\hline Jumlah & & 1641 & 1866 & 2010 & & \\
\hline Rata-rata Kelas & & 63 & 72 & 77 & & \\
\hline Siswa Yang Tuntas & & 9 & 16 & 21 & & \\
\hline Siswa Yang Tidak Tuntas & & 17 & 10 & 5 & & \\
\hline Ketuntasan Klasikal & & $34,6 \%$ & $61,5 \%$ & $80 \%$ & & \\
\hline
\end{tabular}

Tabel 5.

Progres Hasil Belajar Muatan Bahasa Indonesia

\begin{tabular}{|c|c|c|c|c|c|c|}
\hline Nama Siswa & KKM & Pra Siklus & $\begin{array}{c}\text { Nilai } \\
\text { Siklus I }\end{array}$ & $\begin{array}{c}\text { Nilai } \\
\text { Siklus II }\end{array}$ & Progres & Keterangan \\
\hline ATR & 75 & 77 & 76 & 85 & Naik-naik & Tuntas \\
\hline AEP & 75 & 53 & 44 & 67 & Naik-naik & Tidak Tuntas \\
\hline $\mathrm{AM}$ & 75 & 63 & 76 & 82 & Naik-naik & Tuntas \\
\hline AAS & 75 & 65 & 76 & 76 & Naik-tetap & Tuntas \\
\hline AA & 75 & 75 & 79 & 86 & Naik-naik & Tuntas \\
\hline DP & 75 & 55 & 63 & 73 & Naik-naik & Tidak Tuntas \\
\hline EW & 75 & 62 & 76 & 72 & Naik-turun & Tidak Tuntas \\
\hline FFBG & 75 & 78 & 77 & 81 & Naik-naik & Tuntas \\
\hline ITM & 75 & 78 & 86 & 95 & Naik-naik & Tuntas \\
\hline KA & 75 & 56 & 72 & 63 & Naik-turun & Tidak Tuntas \\
\hline $\mathrm{LM}$ & 75 & 58 & 67 & 73 & Naik-naik & Tidak Tuntas \\
\hline MLH & 75 & 75 & 79 & 86 & Naik-naik & Tuntas \\
\hline MA & 75 & 72 & 65 & 77 & Turun-naik & Tuntas \\
\hline MAP & 75 & 69 & 76 & 85 & Naik-naik & Tuntas \\
\hline $\mathrm{MSH}$ & 75 & 53 & 66 & 77 & Naik-naik & Tuntas \\
\hline $\mathrm{MCF}$ & 75 & 80 & 85 & 85 & Naik-tetap & Tuntas \\
\hline NA & 75 & 65 & 76 & 82 & Naik-naik & Tuntas \\
\hline NTR & 75 & 77 & 77 & 81 & Tetap-naik & Tuntas \\
\hline NKS & 75 & 64 & 76 & 86 & Naik-naik & Tuntas \\
\hline $\mathrm{R}$ & 75 & 66 & 59 & 76 & Turun-naik & Tuntas \\
\hline RZ & 75 & 58 & 67 & 77 & Naik-naik & Tuntas \\
\hline RMNAF & 75 & 75 & 81 & 85 & Naik-naik & Tuntas \\
\hline SPP & 75 & 76 & 85 & 90 & Naik-naik & Tuntas \\
\hline SER & 75 & 82 & 82 & 86 & Tetap-naik & Tuntas \\
\hline SNA & 75 & 86 & 86 & 90 & Tetap-naik & Tuntas \\
\hline SA & 75 & 63 & 71 & 81 & Naik-naik & Tuntas \\
\hline Jumlah & & 1781 & 1923 & 2097 & & \\
\hline Rata-rata Kelas & & 68 & 74 & 81 & & \\
\hline Siswa Yang Tuntas & & 11 & 17 & 22 & & \\
\hline Siswa Yang Tidak Tuntas & & 15 & 9 & 4 & & \\
\hline Ketuntasan Klasikal & & $42,3 \%$ & $65,3 \%$ & $84 \%$ & & \\
\hline
\end{tabular}


Berdasarkan Tabel 1 rekapitulasi hasil belajar yang diperoleh siswa dalam mengerjakan teks evaluasi mapel Bahasa Indonesia, menunjukkan adanya sebuah peningkatan hasil belajar yang dialami oleh siswa. Tahap prasiklus, jumlah keseluruhan siswa adalah 26 siswa, sebanyak 9 siswa memperoleh hasil belajar yang sudah baik (tuntas), kemudian sebanyak 17 siswa masih memperoleh hasil belajar yang masih rendah (tidak tuntas) dengan persentase ketuntasan sebesar 34,6\% yang artinya prasiklus hasil belajar siswa belum memenuhi batas ketuntasan yang sudah ditentukan yaitu sebesar $75 \%$.

Siklus I dari jumlah 26 siswa, 16 siswa diantaranya memperoleh hasil belajr yang sudah baik (tuntas) akan tetapi masih ada 10 siswa yang masih memperoleh hasil belajar yang masih rendah (tidak tuntas) dengan persentase ketuntasan sebesar 57,6\% maka dapat disimpulkan bahwa dalam hal ini hasil belajar siswa pada siklus I mengalami peningkatan aka tetapi hasil belajar siswa masih belum memenuhi batas ketuntasan yaitu sebesar 75\%. Tahap siklus II pada muatan Bahasa Indonesia ini dari 26 siswa terdapat 21 siswa yang sudah memperoleh hasil belajar yang sudah baik (tuntas) hanya 5 siswa yang masih memperoleh hasil belajar rendah (tidak tuntas) dengan perrsentase ketuntasan sebesar $80 \%$ yang berarti pada tahap ini hasil belajar siswa mengalami peningkatan yang pesat lagi dibandingkan dengan siklus I. Siklus II sudah memenuhi batas minimal yang ditentukan yaitu $75 \%$ Ketuntasan klasikal dapat disajikan dalam diagram dibawah ini.

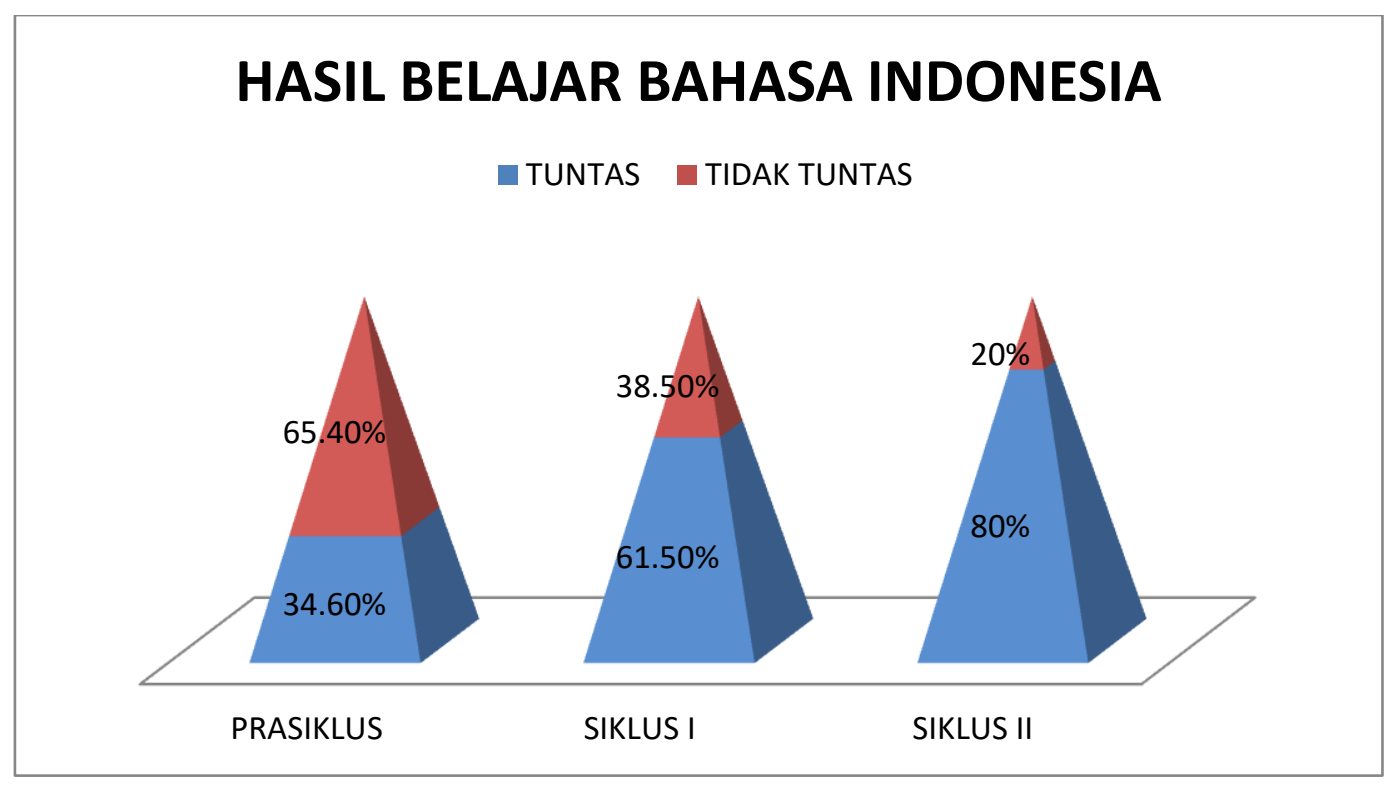

Gambar 1. Hasil Belajar Bahasa Indonesia.

Peningkatan hasil belajar juga di alami pada muatan IPS kelas IV SD 1 Gamong setelah dilakukan tindakan penerapan model pembelajaran Make A Match berbantuan media permainan ular tangga, dari prasiklus, siklus I, siklus II. Berdasarkan tabel 2 diatas, rekapitulasi hasil belajar siswa pada aspek pengetahuan di muatan IPS menunjukkan bahwa adanya peningkatan hasil belajar yang dialami siswa kelas IV di SD 1 Gamong. Tahap prasiklus sebanyak 26 siswa hanya terdapat 11 siswa yang hasil belajarnya sudah baik (tuntas) kemudian sebanyak 15 siswa hasil belajarnya masih dibawah KKM 
(tidak tuntas) persentase yang diperoleh pada prasiklus sebesar $42,3 \%$ yang artinya pada prasiklus hasil belajar siswa masih belum memenuhi batas ketuntasan minimal yang sudah ditentukan yaitu 75\%. Tahap siklus I siswa mengalami beberapa peningkatan pada hasil belajarnya dari 26 siswa terdapat 17 siswa yang mengalami tuntas belajar yang artinya hasil belajar siswa baik kemudian siswa yang masih tidak tuntas dalam belajar sebanyak 9 siswa dengan persentase ketuntasan sebesar 65,3\%. Hal ini dapat disimpulkan bahwa pada siklus I hasil belajar siswa mengalami peningkatan akan tetapi belum memenuhi batas ketuntasan minimal yaitu 75\%. Tahap terakhir yaitu siklus II hasil belajar siswa mengalami peningkatan pesat yaitu dari 26 siswa terdapat 22 siswa yang hasil belajarnya sudah baik (tuntas), siswa yang masih belum berhasil dalam belajar hanya sebanyak 4 siswa saja dengan persentase ketuntasan sebesar $84 \%$ ini dapat disimpulkan bahwa pada siklus II hasil belajar siswa mengalami peningkatan yang artinya di siklus II ini hasil belajar siswa sudah memenuhi batas minimal yang ditentukan yaitu $75 \%$. Ketuntasan klasikal dapat disajikan pada gambar dibawah ini.

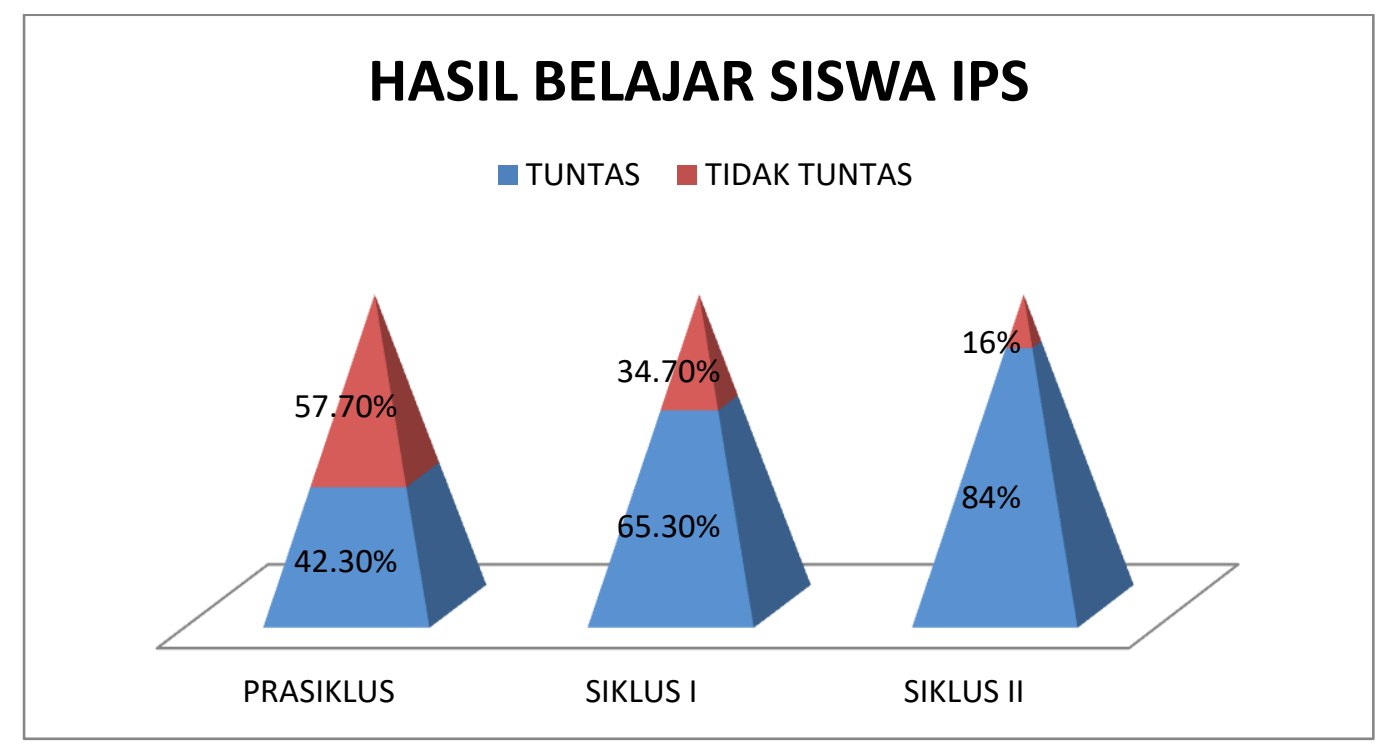

Gambar 2. Hasil Belajar Bahasa Indonesia.

Berdasarkan semua penjelasan diatas aspek pengetahuan siswa yaitu hasil belajar mengalami peningkatan mulai dari prasiklus menuju siklus I dan ke siklus II. Proses pembelajaran tema Indahnya Keberagaman di Negeriku dengan penerapan model pembelajaran Make A Match sudah terlaksana dengan baik hal ini di buktikan dengan adanya peningkatan hasil belajar yang di peroleh oleh siswa. proses pengajaran memang sudah terlaksana dengan maksimal akan tetapi masih ada satu, dua siswa yang masih suka berbicara sendiri dan bermain sehingga dalam mengerjakan evaluasi siswa menjawab kurang tepat.

Hasil penilitian ini diperkuat oleh penelitian yang sudah dilakukan oleh Aliputri (2018) bahwa dalam penelitiannya terdapat peningkatan hasil belajar dalam aspek pengetahuan pada kondisi awal diperoleh hanya mencapai $51 \%$ kemudian di siklus I meningkat menjadi $90 \%$ dan pada siklus II mengalami peningkatan lagi sebesar 94\%. Dari hasil tersebut dapat disimpulkan bahwa dengan 
pendekatan model pembelajaran Make A Match layak digunakan untuk peningkatan hasil belajar siswa.

Pada saat pembelajaran di siklus I masih banyak ditemukan beberapa masalah sehingga mempengaruhi hasil belajar siswa maka dari itu peneliti melakukan tindak lanjut dengan lebih optimal dan melakukan perbaikan dalam pembelajaran di siklus II. Shoimin (2014: 98) berpendapat bahwa dengan menerapkan Make A Match harus di dukung dengan keaktifan siswa, sehingga dalam siklus II melakukan perbaikan agar siswa menjadi aktif dalam pembelajaran. Trianto (2011: 75) mengemukakan bahwa penggunaan media dan bahan ajar dimaksudkan agar anak dapa berekplorasi dengan benda-benda lingkungan sekitarnya. Dengan menerapkan model pembelajaran dan penggunaan media pada proses belajar mengajar dikelas IV SD 1 Gamong ini, akhirnya peneliti berhasil meningkatkan hasil belajar siswa.

\section{KESIMPULAN}

Berdasarkan pelaksanaan penelitian tindakan kelas (PTK) yang telah dilakukan terhadap siswa kelas IV SD 1 Gamong dengan menerapkan model Make A Match untuk meningkatkan hasil belajar siswa pada tema 7 Indahnya Keberagaman di Negeriku menunjukkan bahwa ada peningkatan pada setiap siklusnya dapat disimpulkan sebagai berikut: Pembelajaran yang menerapkan model pembelajaran Make A Match dapat meningkatkan hasil belajar siswa. berdasarkan penelitian hasil belajar pada aspek pengetahuan siswa kelas IV SD 1 Gamong di tahap prasiklus masih memperoleh hasil belajar yang rendah dengan nilai rata-rata siswa yang satu kelasnya terdiri dari 26 siswa untuk muatan Bahasa Indonesia 63 dan hanya 9 siswa yang tuntas dan dengan ketuntasan klasikal sebesar $34,6 \%$ dan nilai rata-rata pada muatan IPS yaitu 68 dengan 11 siswa tuntas dan ketuntasan klasikal sebesar 42,3\% . Pada siklus I peneliti melakukan tindakan dengan menerapkan model pembelajaran Make A Match berbantuan media permainan ular tangga kedalam proses belajar mengajar dapat meningkatkan hasil belajar siswa pada muatan Bahasa Indonesia nilai rata-rata dalam satu kelas yang berjumlah 26 siswa sebesar 72 dengan 16 siswa yang mengalami tuntas belajar dan ketuntasan klasikal mencapai 61,5\% dan nilai rata-rata pada muatan IPS yaitu 74 dengan 17 siswa yang mengalami tuntas belajar dengan ketuntasan klasikal mencapai 65,3\% . pada siklus I hasil belajar siswa masih belum mencapai ketuntasan minimal yaitu $75 \%$. Siklus II peneliti masih menggunakan model pembelajaran Make A Match lagi dalam pembelajaran sehingga mengalami peningkatan pada muatan Bahasa Indonesia dengan rata-rata nilai 77 dengan 21 siswa yang mengalami tuntas belajar dan ketuntasan klasikal mencapai $80 \%$ dan pada muatan IPS dengan rata-rata yang diperoleh 81 dengan 22 siswa yang mengalami tuntas belajar dan ketuntasan belajar mencapai $84 \%$.

\section{DAFTAR PUSTAKA}

Arifin, Zaenal. (2014). Evaluasi Pembelajaran. Bandung: PT Remaja Rosdakarya. Arikunto, Suharsimi, dkk. (2013). Penelitian Tindakan Kelas. Jakarta: Buki Aksara. 
Aqib, Zainal, dkk. (2014). Penelitian Tindakan Kelas. Bandung: Yhama Widya.

Shoimin, Aris. 2014. 68 Model Pembelajaran Inovatif dalam Kurikulum 2013.

Yogyakarta: Ar-Ruzz Media.

Sugiyono. 2010. Metode Penelitian Pendidikan Pendekatan Kuantitatif, Kualitatif, R\&D.

Bandung: Alfabeta.

Trianto. (2011). Model Pembelajaran Terpadu. Jakarta: Bumi Aksara. 